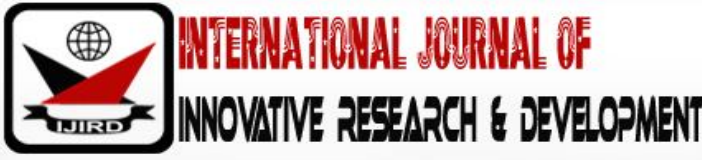

ISSN 2278 - 0211 (Online)

\section{General Principles of Good Governance in State Civil Apparatus Law}

\author{
Mukmin Muhammad \\ Lecturer, Department of Administrative law, STIA Al Gazali Barru, Indonesia
}

\begin{abstract}
:
In order to realize the national objectives, State Civil Apparatus are needed. State Civil Apparatus are assigned the duties to carry out the task of public service of the task of the government and certain development tasks. In order to achieve the national objectives, the government needs professional State Civil Apparatus that are free from political intervention, free from the practice of collusion, corruption and nepotism and capable of acting as the glue of unity and national unity based on Pancasila and the 1945 Constitution of the State of the Republic of Indonesia, which is in line with the Good Governance Principles (algemene beginselen van behorlijk bestuur) which is conceived as a legal rule contained in Law Number 5 Year 2014 on State Civil Apparatus.
\end{abstract}

Keywords: State civil apparatus, good governance

\section{Introduction}

The purpose of the Indonesian Nation as stipulated in the preamble of the 1945 Constitution is to establish an Indonesian state government that protects the entire nation of Indonesia and the entire blood of Indonesia, to promote the common prosperity, to educate the nation and to maintain the world order based on independence, peace, and social justice.

Protecting the whole Indonesian nation and the whole of Indonesia's blood spill means ensuring every nation of Indonesia to obtain its rights and obligations respectively. Promoting public welfare is the task of the Unitary State of the Republic of Indonesia to advance the standard of living of the people to achieve prosperity for the people as a whole. Educating the life of the nation. Keeping the world order based on the freedom of perpetual peace and social justice is the goal of world peace by involving all elements of the world's states to achieve an order and peace (Angger Sigit and Meylani 2016: 2)

To achieve these national goals based on Pancasila and the 1945 Constitution of the State of the Republic of Indonesia, national development in Indonesia is implemented. In order for the planning stage until the implementation of the task of national development and governmental tasks can run as expected, the existence of State Civil Apparatus as executor and control of government projects are needed.

The State of Indonesia is a welfare state that is an evolution from the country of the past which was just a night watchman. The consequence of the welfare state is that the state intervenes in all forms of community activity to ensure the implementation of the welfare of the community. In this case, the role of government is very broad in terms of interfering in community activities.

In order to achieve the national objectives as set forth in the fourth paragraph of the 1945 Constitution of the Republic of Indonesia (UUD 1945), it is necessary that the State Civil Apparatus to be professional, free from intervention, politics, clean of corrupt, collusive and nepotism practices, capable of organizing public services for the community and able to perform the role as a glue of unity and entity of the nation based on Pancasila and the 1945 Constitution. National objectives as stated in the preamble of the 1945 Constitution, to realize the national objectives required Employees of State Civil Apparatus who in duty to carry out public services, and specific development tasks. The task of public service is done by providing services of the goods, services and administrative services provided by civil servants of the state apparatus. The task of government is done for the implementation of general functions of government, including the empowerment of institutional, personnel and management. While for the implementation of certain development tasks, it is carried out through the development of the nation (cultural and political development) and through economic and social development directed to improve the welfare and prosperity of the whole community.

To be able to perform public service tasks of government tasks and specific development tasks, State Civil Apparatus Officers must have a good profession and management based on the merit system or the comparison between the qualifications, competence and performance required by the position with the qualifications, competencies and performance 
of the candidates in the recruitment of appointments, placements and promotions in the positions held openly and competitively in line with good governance.

\section{Discussion}

The shift of nachwachtersstaat (night watch country) conception to welfare state conception brought a shift in the role and activity of the government. In nachwachtersstaat conception, staatsonthouding principle applies, namely the state and government restrictions of social and economic life of society. The government is only a guardian of public order and security while in the welfare state concept, the government is given the obligation to realize besstuurszorg (public welfare), for which the government is given the authority to intervene (statsbemoeienis) in all fields of community life. This means that the government is required to act actively in the midst of the dynamics of community life.

Since the adoption of the welfare state concept, which places the government responsible to the general welfare of citizens and for the realization of this welfare, the government is empowered to intervene in all fields of community life, which in this intervention is not only based on legislation but in certain circumstances can act without relying on legislation but based on its own initiative through Freies Ermessen, it raises concerns among citizens. Due to Freies Ermessen, there is an opportunity for conflict of interest between the government and the people in the form of onrechmatig overheisdsdaad, detournement de fouvoir, and in the form of willekeur, which are forms of deviation from governmental actions which resulted in the deprivation of the rights of the citizens.

In the history of the emergence of Good Governance (Algemene Beginselen van Behoorlijk Bestuur) originated from a sense of fear of some people against freedom of action (Freies Ermessen) from the state administration in carrying out its duties to realize Welfare State, among authors of state administration law there are different translation of Algemene beginslen and behoorlijk. There are some who translate beginslen word with the basic foundations and principles while the word behoorlijk is translated with the best that is worthy and proper. With this translation, algemene beginselen Van behoorlijk bestuur becomes the principles or the basics or general principles of good governance. With reference to this word of origin of behoolijk, all of which indicate adjectives and meaning that it is an agreed, that is bestuur, so the translation of algemene beginslen van berhoolijk bestuur becomes general principles of good governance and is more appropriate in terms of language.

What is meant by good general principles of good governance (algemene begiselen van behorlijk bestuur) is including legal certainty, orderly state administration, openness, proportionality, professionalism, and accountability. In the law number 5 of 2014 on the State civil apparatus there are several articles regulating the State Civil Apparatus such as professional, proportionality, clean of corruption, collusion and nepotism practices can carry out public service in Indonesia. The provision of article 2 of the Act number 5 of 2014 on the State Civil Apparatus formulates the principle of organizing the State Civil Apparatus as follows:

\subsection{Article 2}

Implementation of policy and management of State Civil Apparatus based on the principle:

- Legal certainty

- Professionalism

- Proportionality

- Integration

- Delegation

- Neutrality

- g. Accountabilityh. Effective and efficient

- Openness

- j. Non-discrimination

- k. Unity

- $\quad$ l. Justice and equality

- m. Welfare

In the explanation of Law number 5 of 2014 on State Civil Apparatus article 2 letter:

- The meaning of "principle of legal certainty" is that in every implementation of policy and management, State Civil Apparatus prioritizing the basis of legislation, propriety and justice.

- The meaning of "professional principle" is to prioritize the expertise based on the code of ethics and the provisions of laws and regulations.

- The meaning of "principle of proportionality" is to give priority to equilibrium between the rights and obligations of employees of the State Civil Apparatus.

- The meaning of "the principle integrity" is the management of State Civil Servant Officers based on a nationally integrated management system.

- The meaning of "delegation principle" is that some of the authority of State Civil State Administration can be delegated to the ministry, non-ministerial government institution, and local government. 
- The meaning of "principle of neutrality" is that every State Civil Service Officer does not take sides from any form of influence and does not favor any interest.

- The meaning of "the principle of accountability" is that any activities and outcomes of the activities of the State Civil Service Officer must be accountable to the public in accordance with the provisions of legislation.

- The meaning of "effective and efficient principle" is that in carrying out the management of state civil apparatus in accordance with the target or objectives in a timely manner in accordance with the established plan.

- The meaning of "principle of transparency" is that in the management of State Civil Apparatus is open to the public.

- The meaning of "non-discriminative principle" is that in the management of civil state apparatus, KASN does not distinguish the treatment of gender, tribe, race religion, and class.

- The meaning of "justice and equality" is that the administration of the State Civil Apparatus must reflect a sense of justice and equality in order to gain an opportunity for the function and role of the State Civil Apparatus employees.

- The meaning of "principle of unity and entity" is that civil servants as the glue of the Unitary State of the Republic of Indonesia.

- The meaning of "welfare principle" is that the implementation of the State Civil Apparatus is directed to realize the improvement of the quality of life of the Civil Servants of State Apparatus.

Articles 11 and 12 of Law No. 5 of 2014 on the State Civil Apparatus regulate the duties and roles of the State Civil Servants in public service professionally and freely from practice of Collusion, Corruption and Nepotism.

\subsection{Article 11}

Civil Servants of State Apparatus are on duty to:

- Carry out public policies made by officers of personnel development in accordance with the provisions of legislation.

- Provide a professional and quality public service; and

- Strengthen the unity and entity of the unitary state of the Indonesian Republic.

\subsection{Article 12}

The State Civil Servant officer serves as an executive planner and supervisor of the implementation of general governmental tasks and national development through the implementation of professional public policies and services free from political and clean intervention from politics, corruption, collusion and nepotism.

Whereas from the formulation of articles 11 and 12 of Law No. 5 of 2014 it is well known that a Good Governance will be born from a clean government free from practice of corruption, collusion and nepotism. How to make it happen is presumably back to the state's official and/or civilian apparatus which is in charge of the tasks and responsibilities for carrying out public services of government duties and development tasks.

Thus, it is necessary to build a professional State Civil Apparatus free from clean political intervention from the practice of corruption, collusion and nepotism and able to organize public services for the community and able to perform the role as an adhesive element of unity and national unity based on Pancasila and the 1945 Constitution of the Republic of Indonesia.

In fact, this general principle of good governance, although it is a principle but not all of it, is a general and abstract generalization, and in some cases emerges as a concrete legal rule or set forth in the articles of law and has certain sanctions (Ridwan HR 2016: 237)

The general principle of good governance according to Kuncoro purbopranoto (1975: 29) is as follows:

- The principle of legal certainty

- The principle of balance

- The principle of equality in making decisions

- The principle of acting carefully

- The principle of motivation for every decision

- The principle of does not mix authorities

- The principle of decent game

- The principle of justice and fairness

- The principles of trust and responding to reasonable rewards

- The Principle negates the consequences of a null decision

- The principle of protection of personal views and ways of life

- The principle of wisdom

- The principles of public interest

To realize good governance, it is strongly influenced by the desire of power holders or governmental institutions to realize a good governmental idea by raising the general principles of good governance in the form of concrete legal rules. 


\section{Conclusion}

Based on the description in the discussion then the conclusion put forward is:

- The State of Indonesia is a welfare state which is an evolution of the ancient state which was only as night watchman and the consequences of the welfare state is the state intervened in all forms of community activity

- In order to achieve the national objectives, it is required that the professional Civil State Apparatus free from free political intervention from the practice of collusion, corruption and nepotism, able to organize public services and also serve as a glue of unity and entity of the nation based on Pancasila and the 1945 Constitution

- The meaning of the principle of good general governance (algemene beginselen van behoorlijk bestuur) is including the principle of legal certainty of the administration of the state, openness, proportionality, professionalism and accountability

\section{Advice}

The State Civil Apparatus should be professional, independent, clean, proportionate and accountable in line with good governance principles that are established to create good governance.

The implementation of State Civil Apparatus management should be based on the comparison between the competencies and qualifications required by the positions with the competencies and qualifications of the candidates in the recruitment, appointment, placement and promotion of the position, in line with good governance.

\section{References}

i. Angger Sigit Pramukti dan Meylani,2016,Pengawasan Hukum terhadap Aparatur Negara,Pustaka Yustisia,yogyakarta.

ii. Algra,NE,1951,Rechtsgeleerd Handwordenboek,TwedeDruk,J.B.Walters vitgerersmaatshappij N.V.Groningen.

iii. Bagir Manan,1993,Beberapa Masalah Hukum Tata Negara Indonesia,Alumni,Bandung.

iv. Belifante,AD,1983,Beginselen Van Nederlanse Staatsrecht,Samson Utgeveperij,Alphen aan den Rejin.

v. Kuntjoro Purbopranoto,1975,Beberapa catatan Hukum tata pemerintahan dan peradilan Administrasi Negara,Alumni,Bandung.

vi. Michiels,F.C.M.A,2003,Hoofdzaken Van het Bestuurecht,3e Druk,kluwer,Deventer.

vii. Mukmin Muhammad,2017,Sistem Administrasi Negara Republik Indonesia,Samudra Biru,Yogyakarta.

viii. Mukmin Muhammad, 2018, PembangunanHukum di Indonesia,Cv.Dua Bersaudara,Makassar.

ix. P.P.Craig,2003,Administrative Law,Fift Edition,London: sweet \& Maxwel.

x. Ridwan HR,2016,Hukum Administrasi Negara,Raja GrafindoJakarta.

xi. Sahya Anggara,2012,Perbandingan Administrasi Negara,Pustaka Setia,Bandung.

xii. Sudikno Mertokusumo,2014,Teori Hukum,Cahaya Atma Pustaka,Yogyakarta.

xiii. Undang - Undang Nomor 5 Tahun 2014 Tentang Aparatur Sipil Negara.

xiv. Undang - Undang Nomor 28 Tahun 1999 Tentang Penyelenggaraan Negara yang Bersih danBebasdariPraktikKorupsiKolusidanNepotisme.

xv. Peraturan Pemerintah Nomor 10 Tahun Tahun 2010 Tentang Disiplin Pegawai Negri Sipil. 